\title{
The Effect of Human Resource Management Practices on Employee Performance
}

\author{
Shahid Mahmood ${ }^{1}$, Kamal bin Abdul Hamid ${ }^{2}$, Shahrizal bin Badlishah ${ }^{3}$ \\ ${ }^{1,2,3}$ School of Business Management, College of Business, Universiti Utara Malaysia, Sintok, Malaysia. \\ abkamal@uum.edu.my ${ }^{2}$
}

Article History: Received: 10 November 2020; Revised: 12 January 2021; Accepted: 27 January 2021; Published online: 05 April 2021

Abstract: The present study examines the relationship between HRM practices and performance of employee to be tested in
Punjab police, Pakistan. The sample size in this study is 368 respondents that consists of Inspectors and Sub-inspectors of
Punjab Police Department in Pakistan. We collected data using questionnaire and analysis using Smart-PLS. Our result
discovered that job rotation, training and development, compensation, career planning, and performance appraisal have a
positive affect to Employee Performance in Punjab Policy department, Pakistan. Based on our findings, we suggest the
policymakers to provide more intensive compensation to employees, optimizing job rotation, implementing training and
development, provide appropriate career planning, and making advance performance appraisal in order to improve the
performance of Punjab police employees in Pakistan. This study extends existing literature of Employee Performance, it
delivers new understandings on the conception and role of job rotation, training and development, compensation, career
planning, and performance appraisal to stimulate the reformation of Employee Performance in the government institution
such as the Punjab police department. Keywords: Employee Performance, Job Rotation, Compensation, Training and Development, Career Planning, Performance Appraisal.

\section{Introduction}

In current years, the requirement of employee performance and its fame is at the peak. Several factors behind boost of performance, provision of goods and services, advance medical and mechanical technology, aircrafts and space shuttles, IT, telecommunication, social media, automobiles, mobiles, etc. an increasing competitions among organizations have required organizations to thoughtful of ways to maintain, improve and optimize their employee performance (Koopmans et al., 2012; Palvalin, 2019; Ramos-Villagrasa, Barrada, Fernández-del-Río, \& Koopmans, 2019). Ahmad, Danish, Ali, Ali, and Humayon (Ahmad, Danish, Ali, Ali, \&Humayon, 2018) describes that employees (human resource) are one of the most vital resources of any organization as they subsidize to its growth and success. Similarly, Goštautaitè and Bučiūnienè (Goštautaitė\&Bučiūnienè, 2015) considered employee as an important element for organizational success when properly managed.

The public sector is an institution of government and is established mostly to provide goods and required servicestothegeneralpublicinefficientandeffectivemanner(Inyang\&Akaegbu,2014;ATabiu,2019). Moreover, in modern governance, the public service is regarded as the nerve center of the government administration (Adegoroye, 2006; Olubunmi\&Adesopo, 2017). Study by Bason (Bason, 2018) foundthepublic sector departments and firms have vital role in economic, development, political, social welfare of society. Therefore, public servants (employees) are expected to perform competently in providing these services and many other services to the general public as in developed countries like UK, Australia, Denmark and USA.

Pakistan is the 6th largest country of the world in terms of population. However, the performance of Pakistani public sector employees in the provisions of these very important services and many others are not satisfactory especially at the grassroots level of government (local government areas). There was too muchpublicoutcryonthediminishingstandardofPakistanpolicePerformance, whichhas4partsincluded Punjab police, Sindh police, KPK police and Baluchistan police (Iqbal, Farooq, \&Shabbir, 2019; Shehrani, 2017; Ullah, Hussain, \&Alam, 2016). Prior literature described that Pakistan police instead of helping and providing security, they have threatened businessmen and royal rich families by making false cases and claimed heavy amount as corruption money to remove cases (Asad\& Harris, 2019; Bluth, 2019; Warf, 2019; Wolf,2017).

Since the independence of Pakistan in 1947, there 21 recommended reports for police reforms hadpublishedthatwererarelyappliedandthePoliceActof1861, whichwasannouncedbytheBritishcolonial powers to suppress political uprisings or opposition, remained operative (Babakhel, 2018). Due to serious internal security challenges, this lack of political ownership has greatly diminished the public safety in Pakistan. Several reform measures had been introduced by different successive governments all with sole aim of improving the employee performance of Police so that efficient service deliveries will be provided to the general public (Faisal \&Jafri, 2017). For instance, from Pakistan independence in 1947 to 2020, therearenumberofreformsinthePakistanPunjabpoliceServices(PPS)introducedbutcan'tbesuccessful due to 
opposition of Bureaucracy and lack of political ownership (Human Right Watch,2016).

In the last three decades, the security issues have been elevated in the province of the Punjab (Pakistan) whichultimatelyprimestothebreakdownofthecountry's economy(Laeeq,Shahzad, Ramalu \&Habiba, 2016). Also, De-Cenzo, Robbins, and Verhulst (2016), noted that several other factors had affected HRM practices in Pakistan, like lack of internal efficient manpower to complete all necessary tasks and poor application of HRM practices. In this regard, Khan, Raziq, and Ghouri (2019) stressed that any organization without a well-tailored and structured HRM policies/practices risk poor performance of employees. From the above mentioned employee performance related to problems and deficiencies in the Pakistan Punjab police, it is argued here that majority can, if not all the problems could be solved by appropriate, effective and efficient HRM practices that can adequately address these unfortunate situations (KhuramShahzad, Bajwa, Ansted, Mamoon, \&Khaliq-urRehman,2016).

Based on issue above, the aims of this study are to investigate the effect of Job Rotation, compensation, career planning, performance appraisal, Training and development of Employee Performance in the Punjab Police, Pakistan. Specifically, the present study intends to address this above gap findings on previous studies by incorporating compound performance to provide a measurement of employee performance with effect of different set of above-mentioned variables in context of Pakistan that ignored on the relevant previous studies. This study expected to contribute to useful recommendation to policymakers in order to improve the performance of security employees of government institution like police in Pakistan. Moreover, this study also expected to provide new knowledge regarding study about development of human resource management.

\section{Literature Reviews}

\subsection{Relationship between Job Rotation and EmployeePerformance}

Jobrotationpracticeisamethodemployedbyorganizationsinordertoimprovetheirworkersperformance and make them more committed towards their work (Mohan \&Gomathi, 2015). Job rotation enables employees in the organization to be aware and also be equipped with the necessary rudiments of their job processestherebymakingthemmoreversatileandcompetent toperformanytaskgiventothemwithlittle or even no supervision (Oparanma\&Nwaeke, 2015). Review of empirical studies on job rotation and employee performance indicated a positive association between the two variables (Hosseiniet al., 2015; Khan et al., 2014). To be more specific, the study by Khan et al., (2014) and Hosseiniet al., (2015) found significant positive relationship between job rotation and performance of bank employees in Pakistan. They supported that adoption of effective job rotation practice in organization brings high employee performance andcommitment.

In addition, the study of Rashkiet al. (Rashki, Hasanqasemi, \&Mazidi, 2014) revealed that movement of employeefrom onedutyposttoanother withintheorganizationpromotehighemployeeperformance. Job rotation, as perceived by the employees enable them to acquire new skills and knowledge. However, the result from the study of Saravani and Abbasi (Saravani\&Abbasi, 2013) indicated that the relationship betweenjobrotationandemployeeperformancewasnotdirectrelationshipbutrather indirectthroughthe mediation of employee job satisfaction. Moreover, Casad (Casad, 2012) argued that job rotation practice develops abilities and skills (e.g., knowledge), that help in identifying and optimize employees' strengths (e.g., capacities), and positively influence their willingnessto perform. Similarly, Way (Way, 2002)

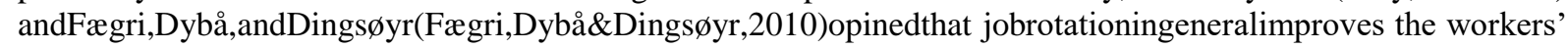
problem-solving competencies, abilities and skills that enable them to produce superior performance in organization. Based on the above argument and empirical supports, the present study proposed the followinghypotheses:

$\mathrm{H} 1$ : Job rotation is positively related to employee performance

\subsection{Relationship between Training \& Development and EmployeePerformance}

Training \& development refers to all the methods used by organizations to give both new and existing (already working) employees the required skills, knowledge and other abilities needed to perform their jobs in organization (DeNisi\& Griffin, 2001). Training \& development practice is considered as one of the most significant and effective process intended to achieve positive result in the strategic HRM (Jerez Gómez,CéspedesLorente\&ValleCabrera,2004).Previousresearchesthatstudytherelationshipbetween training \& development and employee performance have reported a positive relationship (Cho \&Yoon, 2009; Marwat, Qureshi, \&Ramay, 2006; Tessema\&Soeters, 2006). The study by Akhteret al. (2013) revealed that training \& development have significant positive impact on employee performance, and this finding was consistent with 
previous studies (Amin et al., 2013; Jagero, Komba, \&Mlingi, 2012; M. I. Khan, 2012; Nadarasa, 2013; Abubakar Tabiu\&Nura, 2013; Tiwari,2011).

Additionally, the study by Dysvik and Kuvaas (2008) shows that perceived training opportunities explained 13 per cent of the variance in task performance, 19 per cent of the variance in contextual performance. This was in line with the work of Rehman, Mansoor, Rafiq, and Rashid (Rehman, Mansoor, Rafiq, \& Rashid, 2011) who postulated that training \& development have significant positive relationship with employee performance. Similarly, the recent study by Falolaet al. (2014) and Issahakuet al. (2014) provided evidences that training \& development positively influence employee performance. Moreover, Smith and Hayton (1999) supported that training \& development of employees is an important factor that developed the workers towards adaptability to changes as well as adoption to new situations. In addition to the above empirical support, the Social Exchange Theory (SET) (Blau, 2017) argued that when the management of an organization provided employees with sufficient training\& development opportunities, this will send message to employees that the organization cares for its employees' development (Aguinis, 2009). From the above empirical and theoretical supports, this study formulates the hypothesesbelow.

H2: Training \& development is positively related to employee performance.

\subsection{Relationship between Compensation and Employeeperformance}

Compensation practice is considered to be one of the key HRM functions in organization. Compensation conceptualized as the forms of rewards or pay given to the employees by the organization in relation to their employment (Singh, 2012). Compensation in organizational setting refers to the financial and non- financial intrinsic or extrinsic system of rewards that are provided by an organization for the time, skills and efforts made by employees toward fulfilling job requirements, aimed at achieving the organizational objectives (Dowling, Festing, \& Engle, 2008). Previous studies have empirically supported a positive association between the perception of employee on compensation practices and their performance in organization (Baloch et al., 2010; Marwat et al., 2006; Shahzad et al., 2008). In addition, the study by Nadarasa (2013) found a positive relationship between perceived compensation practice and employee performance.

Many studies like Hameed, Ramzan, Zubair, Ali, and Arslan (2014), Oluigbo and Anyiam (2014), Sopiah (2013) as well as Quartey and Esther (2013) supported a positive relationship between perceived compensation practice and employee performance. In contrast, the study of Bowra (2012) did not found relationship between perceived compensation practice and employee performance. Theoretically, SET (Blau, 2017) provided a theoretical support for the relationship between compensation practice and employee performance. The SET argued that, in a social relationship the reciprocity and good gesture between two parties govern the entire relationship. In this regard, if employee perceived that the organizationprovidedhim/her withappropriatecompensation(bothfinancialandnonfinancial), thensuch employeewilltendtoreciprocate withgoodperformance(task,contextualandadaptive). Theseempirical and theoretical support lead to the followinghypotheses:

H3: Compensation is positively related to employee performance.

\subsection{Relationship between Career Planning and EmployeePerformance}

CareerplanningisanimportantHRMpracticeofidentifyingemployees'career preferencesandsettingup a development objective by establishing an action plan that enable employees to match their capabilities and interests with organizational available opportunities (Ismail, Adnan, \& Bakar, 2014). Gardner et al. (2011), observed that individuals (employees) mostly prefer to join the organization that provides enough opportunities to attain their career goals and fully displayed their potential. Through career planning practice, organizations designed favorable systems that provide opportunities for employees to develop and improve their skills, administrative knowledge and new technologies that increase the employees' abilities and performance (Pynes, 2009). Empirical studies on the relationship between career planning and employee performance revealed that there is a significant positive relationship (Akhter, Siddique, \&Alam, 2013; Khalid, AbdulRehman, \& Ilyas, 2014; Nadarasa,2013).

Specifically, the study of Khalid et al. (2014) provided empirical evidence on the positive relationship between career planning and employee performance. The study also argued that the career planning practice provided by organizations inspires the individual employees in the organization to excel in performance. Similarly, the study of Akhteretal. (2013), Tiwari (2011) and Nadarasa (2013) that also provided another empirical support on the significant influence of career planning and development practice on employee performance. Their study also revealed that employees attached strong importance to their career development 
opportunity, and they prepare to work for an organization that provides better career development practice. Therefore, attaining career opportunities and success within the organization is obtainable through career planning. Based on the above empirical studies and theory that supported positive links between career planning and employee performance, this study formulated the followinghypotheses:

$\mathrm{H} 4$ : Career planning is positively related to employee performance.

\subsection{Relationship between Performance Appraisal and EmployeePerformance}

PerformanceAppraisal/review/evaluationisaregularreviewofanemployee'sjobperformanceandoverall contribution (Cappelli\&Tavis, 2016; Cleveland, Murphy, \& Williams, 1989; Gruman\& Saks, 2011; Mone\& London, 2018). Performance appraisal is considered as one of the core functions of human resource management and it was given more focus by the researchers to check its relationship with performance (Arshad, Masood, \&Amin, 2013; Dulebohn\& Ferris, 1999; Osma, 2013). Performance appraisalcharacteristicallyconsistsofaformofHRMpracticesthattheHRdepartmentofanorganization demands every superior to complete on every subordinate once in every year. Fair performance appraisal is a critical tool for the organization in order to get the best of its employees' performance (Dello Russo, Miraglia\&Borgogni,2017)andtheuseofperformanceappraisaliswell-knownandcurrentneed(Pichleretal.,2016).

AMOtheorycansupporttherelationshipbetweenperformanceappraisalandemployeeperformance(task, contextual and adaptive). Performance appraisal practice in an organization can enhance the employee performance through review performance and an increase in human resource (employees) capabilities, motivationandopportunities, thattranslateintohigherperformanceoutcomesandbehaviors(Appelbaum, Bailey, Berg, Kalleberg, \&Bailey, 2000). Boxall and Purcell (2003) considered AMO theory as the best theory of human performance by asserting that if our concern is to manage an individual (i.e. employee) human performance in organization more effectively, then organization should actually start with AMO theory. AMO theory is used to explain the relationship between performance appraisal practice and employees' performance at individual levels research (Paauwe, 2009). Accordingly, based on AMO theory, if in any organization has the best performance appraisal system then the best will be the performance of such organization's employees (Jiang, Takeuchi, \&Lepak, 2013). Based on the above empirical studies and theory that supported positive links between performance appraisal and employee performance, this study formulated the followinghypotheses:

H5: Performance appraisal is positively related to employee performance.

Research framework

Based from the literature, we developed research framework as follow:

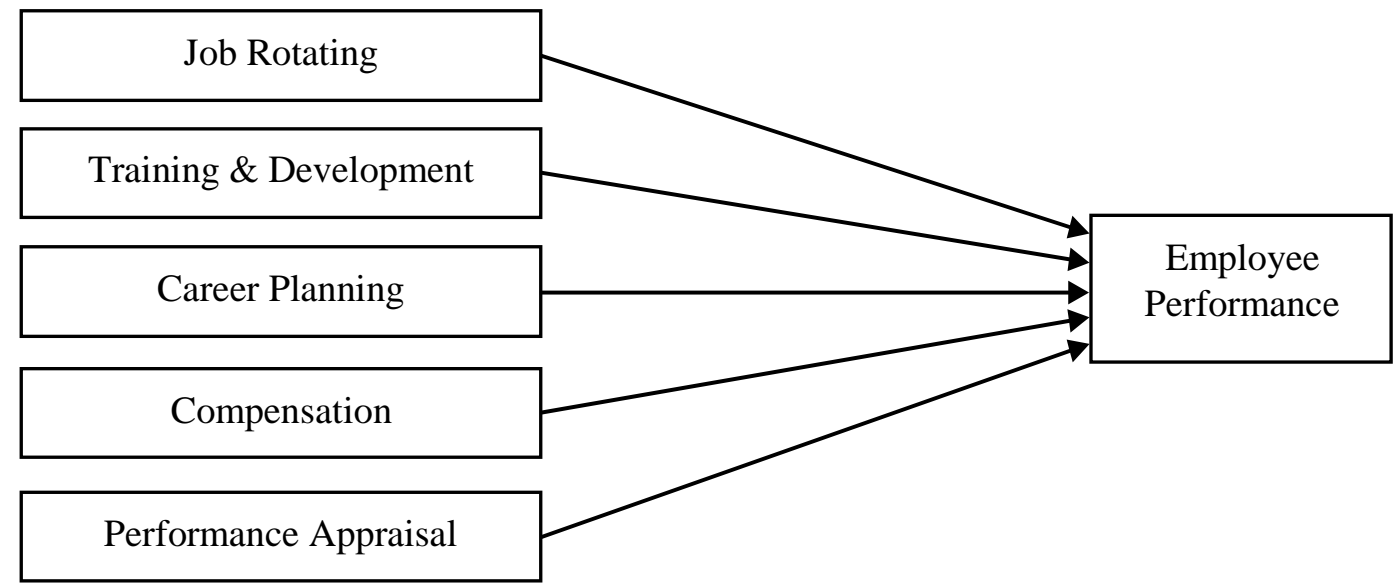

Figure 1. Research Framework

\section{Data And Methodology}

Data collection procedure is regarded as an essential part of research design (Sekaran\&Bougie, 2013). In this study researcher consider only Inspectors and Sub-inspectors of Punjab police as respondents because they are the officers usually promoted from constable based on their high qualifications and best performance. Total population of this study is 8009 (1670 Inspectors and 6339 Sub-inspectors) and then researcher employing the Krejcie-Morgan table provided by Krejcie and Morgan (Krejcie\& Morgan, 1970) to determines sample size in this study. Based on the Krejcie-Morgan table, the appropriate sample sizefor populationfrom8,000to9,000is368. Inordertoavoidmissingofdata,researcherdistributed400 questionnaires to the respondents and then selected only 
368 questionnaires used for dataanalysis.

The present study utilized the Smart Partial least Square Structural Equation Modeling (SmartPLS-SEM) version3.SmartPLS-SEMhassomeadvantagesoverotherrelatedSEM,likeLISRELandAMOSthatare covariancebased (Imran, Hamid, Aziz, \&Wan, 2019). In contrast, the PLS-SEM is a component-based approach with algorithm that minimizes the variances of all the dependent latent construct rather than just explainingthecovariancealone(Urbach,N.,andAhlemann,2010).Additionally,SmartPLS-SEMplaces only minimal restrictions on measurement scales, sample size and residual distribution (Pavlou\&Fygenson, 2006). The Smart PLS-SEM is a second-generation statistical tool that enables researchers to analyze simultaneously multiple variables.The PLSSEM is regarded as a family member of regression techniques design to estimate simultaneously the relationships or links between the structural model (constructs) and measurement model also called indicators (Chin, Marcolin, $\&$ Newsted, 2003). The literature indicated that there are two stages in conducting PLS-SEM analysis that is the measurement modelassessmentandthestructuralmodelassessment(HairJr,Sarstedt,Hopkins, \&Kuppelwieser,2014). The present study assessed both measurement model and structural model in itsanalysis.

\section{Analysis And Result}

The First step in PLS SEM analysis is the structural model assessment. To assess the measurement model within PLS-SEM are involved several tests. It is starting from determining reliability individual items throughexaminingtheouterloadingsofeachconstructor simplecorrelationofindicators. Thecommonly usedmeasureofinternalconsistencyinstrumentinPLSSEMiscompositereliabilityandCronbach'salpha(Barroso, Carrión, \&Roldán, 2010). The factor loading of the items and measurement model in the study are mentioned in table 1 and figure 2, respectively.

Table 1.Outer Loading

\begin{tabular}{|c|c|c|c|c|c|c|}
\hline ITEM & $\mathrm{CM}$ & CP & EP & JR & PA & TD \\
\hline CM1 & 0.826 & & & & & \\
\hline CM2 & 0.870 & & & & & \\
\hline CM3 & 0.811 & & & & & \\
\hline CM4 & 0.852 & & & & & \\
\hline CM5 & 0.840 & & & & & \\
\hline CM6 & 0.854 & & & & & \\
\hline \begin{tabular}{|l}
$\mathrm{CP} 1$ \\
\end{tabular} & & 0.782 & & & & \\
\hline$\overline{\mathrm{CP} 2}$ & & 0.753 & & & & \\
\hline$\overline{\mathrm{CP} 3}$ & & 0.808 & & & & \\
\hline CP4 & & 0.835 & & & & \\
\hline$\overline{\text { CP5 }}$ & & 0.835 & & & & \\
\hline CP6 & & 0.797 & & & & \\
\hline CP7 & & 0.880 & & & & \\
\hline CP8 & & 0.843 & & & & \\
\hline EP1 & & & 0.874 & & & \\
\hline EP2 & & & 0.790 & & & \\
\hline EP3 & & & 0.744 & & & \\
\hline EP4 & & & 0.839 & & & \\
\hline EP5 & & & 0.809 & & & \\
\hline EP6 & & & 0.823 & & & \\
\hline EP7 & & & 0.854 & & & \\
\hline EP8 & & & 0.755 & & & \\
\hline EP9 & & & 0.762 & & & \\
\hline EP10 & & & 0.901 & & & \\
\hline EP11 & & & 0.845 & & & \\
\hline$\overline{\mathrm{EP} 12}$ & & & 0.769 & & & \\
\hline \begin{tabular}{|l|}
$\mathrm{JR} 1$ \\
\end{tabular} & & & & 0.854 & & \\
\hline JR2 & & & & 0.758 & & \\
\hline JR3 & & & & 0.828 & & \\
\hline JR4 & & & & 0.803 & & \\
\hline JR5 & & & & 0.850 & & \\
\hline
\end{tabular}




\begin{tabular}{|l|l|l|l|l|l|l|}
\hline JR6 & & & & 0.820 & & \\
\hline JR7 & & & & 0.774 & & \\
\hline JR8 & & & & 0.784 & & \\
\hline JR9 & & & & 0.888 & & \\
\hline PA1 & & & & & 0.767 & \\
\hline PA2 & & & & & 0.818 & \\
\hline PA3 & & & & & 0.828 & \\
\hline PA4 & & & & & 0.912 & \\
\hline PA5 & & & & & 0.871 & \\
\hline TD1 & & & & & & 0.768 \\
\hline TD2 & & & & & & 0.755 \\
\hline TD3 & & & & & & \\
\hline TD4 & & & & & & 0.855 \\
\hline TD5 & & & & & & 0.895 \\
\hline
\end{tabular}

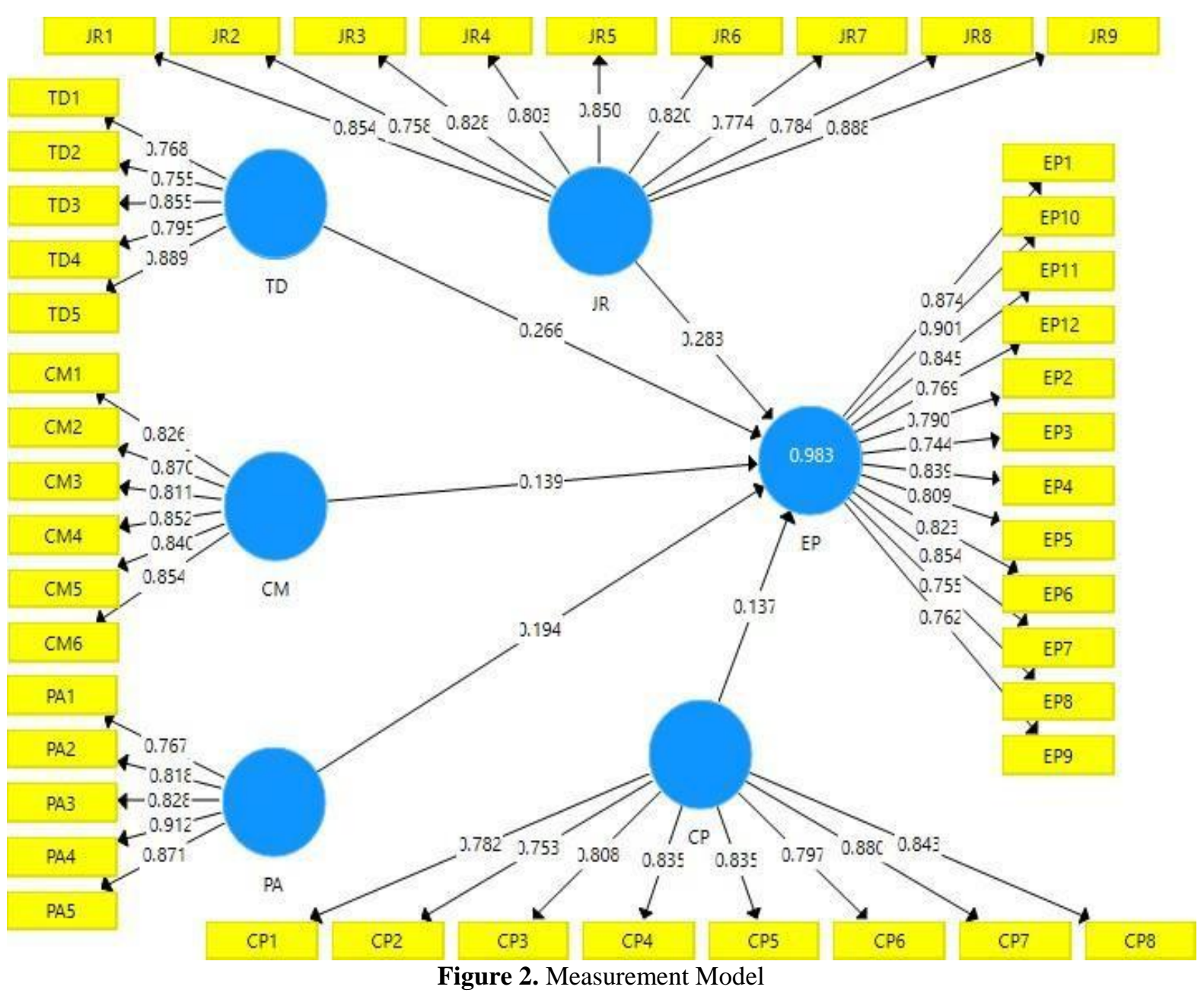

From the results mentioned above, all scales are satisfied with the next condition. In order to understand the implication and worth of the collected data from the respondents, it is very important to calculate the reliability and validity. In order to find the validity, discriminant validity and convergent validity are very useful. In the present study, the reliability of the constructs is calculated through Composite Reliability (CR) and Cronbach Alpha. Researchers have mentioned that the value of composite reliability and Cronbach Alpha coefficient must be more than 0.7 (Fornell\&Larcker, 1981). In the present study, the value of CR is more than 0.7, as evident from the table 2. AVE was used in the present study, so the convergent validity can be established. The value of AVE coefficient must be greater than 0.5 in order to establish the convergent validity of the data collected (Sarstedt, Ringle, Henseler, \& Hair, 2014). According to table 2 below, all these values meet the condition mentioned by Sarstedt et al. (2014). 
Table 2. Construct Reliability and Validity

\begin{tabular}{|l|l|l|l|l|}
\hline Construct & Cronbach's Alpha & rho_A & Composite Reliability & $\begin{array}{l}\text { Average } \\
\text { Variance Extracted }\end{array}$ \\
\hline CM & & & \\
\hline CP & 0.918 & 0.919 & 0.936 & 0.710 \\
\hline EP & 0.929 & 0.931 & 0.941 & 0.668 \\
\hline JR & 0.954 & 0.955 & 0.959 & 0.665 \\
\hline PA & 0.938 & 0.940 & 0.948 & 0.670 \\
\hline TD & 0.895 & 0.900 & 0.923 & 0.706 \\
\hline
\end{tabular}

The discriminant validity measures the extent to which an individual construct is different from other constructs. In the assessment of discriminant validity, Fornell and Larcker (1981) recommended that theAVEmostbehigherthanthevariancebetweenthevariableandothervariablesinthemodel.Thisanalysis is done in table 3below.

Table 3.Discriminant Validity

\begin{tabular}{|l|l|l|l|l|l|l|}
\hline & CM & CP & EP & JR & PA & TD \\
\hline CM & 0.842 & & & & & \\
\hline CP & 0.914 & 0.817 & & & & \\
\hline EP & 0.942 & 0.959 & 0.815 & & & \\
\hline JR & 0.931 & 0.945 & 0.977 & 0.819 & & \\
\hline PA & 0.901 & 0.917 & 0.958 & 0.938 & 0.840 & 0.814 \\
\hline TD & 0.900 & 0.942 & 0.971 & 0.955 & 0.931 & \\
\hline
\end{tabular}

ThesecondstageinPLSSEManalysisisthestructuralmodelassessment.Tomeasurethestructuralmodel, standard bootstrapping procedures will be followed with 5000 sample as recommended by scholars (Hair Jretal., 2014; Henseler, Ringle, \&Sinkovics, 2009). Measuring the structural model allows for the assessment and ascertaining the significance of path coefficient (Hair Jretal., 2014), the coefficient of determination $\mathrm{R}^{2}$, the effect size of all the relationships and lastly the predictive relevance of all models (Hair, Ringle, \&Sarstedt, 2012; Urbach, N., and Ahlemann, 2010). Figure 3 below depicts the structural model of the presentstudy.

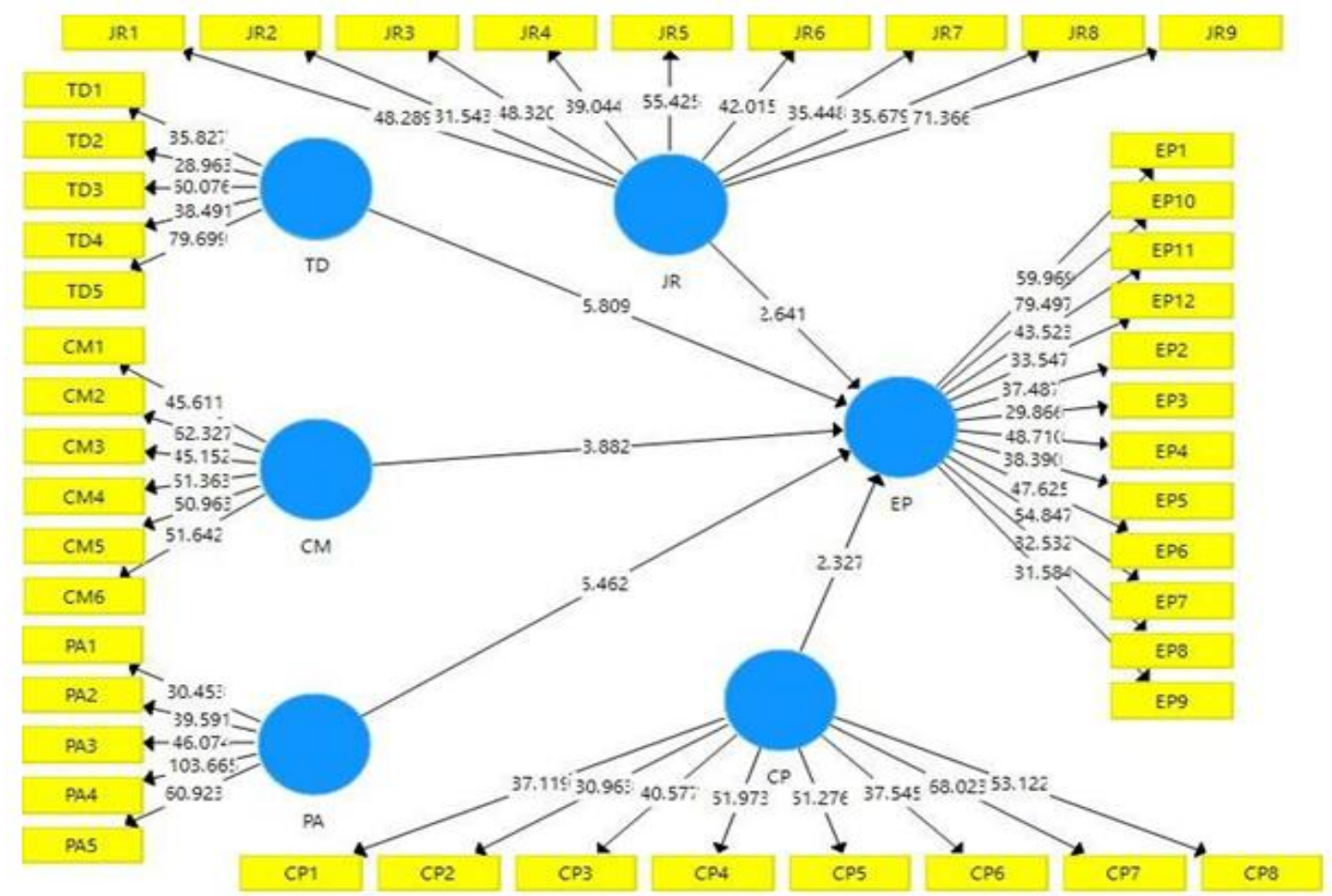


Figure 3.Structural Model.

Table4showsthedirectassociationbetweenthevariables.Inorder todeterminethesignificancebetween the variables, $\mathrm{P}$ values and $\mathrm{t}$ values are calculated. We reject null hypothesis and concluded there are a significant effect between the variables if $\mathrm{t}$-value is more than 1.96 and P-values is less than $0.05(<5 \%)$. Based on table 4 , Ourfindings can be describing as follows. First, Compensation (CM) has a positive affect to Employee Performance, where an increase in Compensation (CM) at $1 \%$ will leads increase in Employee Performance (EP) by $0.129 \%$. It implies that an increase in compensation will stimulates increase the performance of Punjab Police employees in Pakistan. Second, Career Planning (CP) has a positiveaffecttoEmployeePerformance, whereanincreaseinCareerPlanning(CP)at1\% willimprove Employee Performance (EP) at $0.137 \%$. It is shows that career planning potentially motivates Punjab police employees to improve their work performance.

Table 4. Direct Effect.

\begin{tabular}{|l|c|c|c|c|c|}
\hline & Original Sample & Sample Mean & $\begin{array}{l}\text { Standard } \\
\text { Deviation }\end{array}$ & T Statistics & P Values \\
\hline CM EP & 0.139 & 0.128 & 0.036 & 3.824 & 0.000 \\
\hline CP $\rightarrow$ EP & 0.137 & 0.138 & 0.056 & 2.433 & 0.015 \\
\hline JR EP & 0.283 & 0.309 & 0.101 & 2.807 & 0.005 \\
\hline PA tEP & 0.194 & 0.188 & 0.037 & 5.305 & 0.000 \\
\hline TD EP & 0.266 & 0.254 & 0.043 & 6.202 & 0.000 \\
\hline
\end{tabular}

Third, Job Rotation (JR) has a positive affect to Employee Performance (EP), where an enhance in Job Rotation (JR) at $1 \%$ can rise Employee Performance (EP) at $0.283 \%$. It is shows that Job Rotation can promote the performance of Punjab police employees. Fourth, Performance Appraisal (PA) has a positive affecttoEmployeePerformance(EP), whereanenhanceinPerformanceAppraisal(PA)at1\% willcaused

EmployeePerformance(EP)increaseat $0.194 \%$. Itisshowsthat enforcementofperformanceappraisalon thePunjabpoliceemployees willimprovetheirperformance.Fifth,TrainingandDevelopment(T\&D)has a positive affect to Employee Performance (EP), where an enhance in Training and Development (T\&D) at $1 \%$ will caused Employee Performance (EP) increase at $0.254 \%$. It is implying that implementation of Training and Development (T\&D) toward the Punjab police employees will promotetheirperformance.

Furthermore, in order to determine the impact of the IV's on DV, R-square and Adj. R-square are calculated. According to the table 7 below, Employee Performance impacted around $98.3 \%$ by the independent variables, while the rest are influenced by other indicators that not considering in this study.

Table 5. R-Square

\begin{tabular}{|c|c|c|}
\hline DV & R-Square & Adj. R-Square \\
\hline EP & 0.983 & 0.982 \\
\hline
\end{tabular}

\section{Discussion And Conclusion}

Overall,ourfindingsrevealedthatcompensation,careerplanning,jobrotation,performanceappraisal,and training and development are positively improving performance of Punjab police employees. An increase in compensation is considered to motivate employees to be more disciplined and improve their performance. It is consistent with the findings from previous studies (Hameedetal, 2014; Oluigbo and Anyiam, 2014, Sopiah, 2013; Quartey\& Esther, 2013) that concluded that compensation is a supporting element that stimulates improvement in employee performance. Implementation of career planning is very beneficial for employees because it indirectly directs employees to develop more professionally in their work. This result supported the viewpoint of previous studies which concluded that planning hasapositivevalueindevelopingemployeepotentialinanorganization(Akhteretal.,2013; Khalidetal., 2014).

This research also shows that the application of job rotation provides a better work experience for employeesandindirectlyincreasestheprofessionalismofemployeesattheworkplace.Itisconsistentwith the findings of Hosseinietal. (2015) and Khan et al. (2014) that also concluded that job rotation is useful for improving job experience of employee and certainly influences their work performance. This study also reveals that performance appraisal motivates employees to be more professional and responsible in 
theirwork.ThisfindingisinaccordancewiththeviewofArshadetal.(2013)andOsma(2013) who argue that performance appraisal is a useful practice for organizations to motivate employee performance. Furthermore, this study found evidence that training, and development has a positive impact on employee performance development. This finding is certainly in accordance with the theory and previous studies (Amin et al., 2013; Jageroetal., 2012; Khan, 2012; Nadarasa, 2013; Abubakar Tabiu\&Nura, 2013) which concluded that the application of training and development is one way to increase the knowledge and skills ofemployees.

This study provides practical contribution that useful for the policymakers on the Punjab policeinstitution. Based on our study, we recommend that policymakers in Pakistan pay more attention to the welfare of Punjab police officers by compensating them according to their performance. The implementation of job rotation may improve employee experience and indirectly improving the performance of Punjab police officers. Apart from that, we also think that performance appraisal, career planning, and training and development should be optimized in order to motivate the discipline and professionalism of Punjab police officers. Moreover, this study also has limitations such as restricted respondent only within middle senior official levels (Inspectors and Subinspectors) on the Punjab police institution but the higher and the lower official levels ignored. So, it is recommended for future study to collected data with the respondent within various employee levels in order to provide a better result.

\section{Acknowledgement}

Great thanktoUUMforsupportthisstudyandalsoforPunjabPoliceInstitution for permission to collected data.

\section{References}

1. Adegoroye, G. (2006). Public service reform for sustainable development: The Nigerian experience. In Paper presented at the Keynote Address at the Commonwealth Advanced Seminar, Wellinton, New Zealand.

2. Aguinis, H. (2009). An expanded view of performance management.Performance Management: Putting Research into Action.

3. Ahmad,D.I.,Danish,D.R.Q.,Ali,S.A.,Ali,H.F.,\&Humayon,D.A.A. (2018).AComparativeStudy of Banking Industry Based on Appraisal System, Rewards and Employee Performance.SEISENSE Journal of Management, 2(1),1-11.

4. Akhter,M.M.,Siddique,M.N.-E.-A.,\&Alam,M.A.(2013).HRMPracticesanditsImpactonEmployee Performance: A Study on the Cement Industry in Bangladesh. Global Disclosure of Economics and Business, 2(2),192-199.

5. Amin, A., Saeed, R., Lodhi, R. N., Mizna, Simra, Iqbal, A., \&Rida-e-Tehreem. (2013). Theimpact of employees training on the job performance in education sector of Pakistan. Middle East Journal of Scientific Research, 17(9), 1273-1278.

6. Appelbaum, E., Bailey, T., Berg, P., Kalleberg, A. L., \& Bailey, T. A. (2000).Manufacturing advantage: Why high-performance work systems pay off. Cornell University Press.

7. Arshad, M., Masood, M., \&Amin, G. (2013).Effects of Performance Appraisal Politics on Job Satisfaction, TurnoverIntentionandLoyaltytoSupervisor.InternationalReviewofManagementand BusinessResearch.

8. Asad, A. Z., \& Harris, R. (2019).The politics and economics of drug production on the PakistanAfghanistan border.Routledge.

9. Babakhel, A. M. (2018). Police Reforms. Retrieved March 30, 2020, from https://www.dawn.com/news/1410471/police-reforms

10. Baloch, Q. B., Ali, N., Kiani, T. S., Ahsan, A., \&Mufty, A. (2010). Relationship between HR Practices and Perceived Employees' Performance of Bankers in NWFP, Pakistan (AnEmpirical Evidence). European Journal of Social Sciences, 18(2),210-214.

11. Barroso, C., Carrión, G. C., \&Roldán, J. L. (2010). Applying maximum likelihood and PLS on different sample sizes: studies on SERVQUAL model and employee behavior model. In Handbook of Partial Least Squares (pp. 427-447). Berlin: Springer.

12. Bason, C. (2018). Leading public sector innovation: Co-creating for a better society (2nd ed.). Policy Press.

13. Blau, P. M. (2017). Exchange and power in social life. New York: Routledge.

14. Bluth, C. (2019). Security, Culture and Human Rights in the Middle East and South Asia.Xlibris Corporation.

15. Bowra, Z. A. (2012). Impact of human resource practices on employee perceived performance in banking sector of Pakistan. African Journal of Business Management, 6(1), 323-332. 
16. Boxall, P., \& Purcell, J. (2003).Strategy and human resource management. New York: Palgrave Macmillan.

17. Cappelli, P., \&Tavis, A. (2016).The Performance Management Revolution.Harvard Business Review, 94(10), 58-67.

18. Casad, S. (2012).Implications of job rotation literature for performance improvement practitioners.Performance Improvement Quarterly, 25(2), 27-41.

19. Chin, W. W., Marcolin, B. L., \&Newsted, P. R. (2003). A partial least squares latent variable modeling approach for measuring interaction effects: Results from a Monte Carlo simulation study and an electronic-mail emotion/adoption study. Information Systems Research, 14(2), 189-217.

20. Cleveland, J. N., Murphy, K. R., \& Williams, R. E. (1989). Multiple uses of performance appraisal: Prevalence and correlates. Journal of Applied Psychology, 74(1), 130-135.

21. DeCenzo, D. A., Robbins, S. P., \&Verhulst, S. L. (2016). Fundamentals of human resource management(12th ed.). John Wiley \& Sons, Inc.

22. Dello Russo, S., Miraglia, M., \&Borgogni, L. (2017).Reducing Organizational Politics in Performance Appraisal: The Role of Coaching Leaders for Age-Diverse Employees.Human Resource Management, 56(5), 769-783.

23. Dowling, P. J., Festing, M., \& Engle, A. D. (2008).International Human Resource Management: Managing People in a Multinational Context (5th ed.). London: Cengage Learning.

24. Dulebohn, J. H., \& Ferris, G. R. (1999).The role of influence tactics in perceptions of performance evaluations' fairness.Academy of Management Journal, 42(3), 288-303.

25. Dysvik, A., \&Kuvaas, B. (2008). The relationship between perceived training opportunities, work motivationandemployeeoutcomes.InternationalJournalofTrainingandDevelopment, 12(3),138- 157.

26. Fægri, T. E., Dybå, T., \&Dings øyr, T. (2010).Introducing knowledge redundancy practice in software development: Experiences with job rotation in support work.Information and Software Technology, 52(10), 1118-1132.

27. Faisal, F., \&Jafri, A. R. (2017). Corruption as a source of failure of good governance and management in Pakistan: proposed remedial measures. Journal of the Punjab University Historical Society, 30(1), 57-75.

28. Falola, H. O., Osibanjo, A. O., \&Ojo, I. S. (2014). Effectiveness of Training and Development on Employees' Performance and Organization Competitiveness in the Nigerian Banking Industry. Bulletin of the Transilvania University of Brasov, 7(1), 161-170.

29. Fornell,C.,\&Larcker,D.F.(1981).EvaluatingStructuralEquationModels withUnobservableVariables and Measurement Error.Journal of Marketing Research, 18(1),39.

30. Gardner, T. M., Wright, P. M., \& Moynihan, L. M. (2011).The impact of motivation, empowerment, and skillenhancing practices on aggregate voluntary turnover: The mediating effect of collective affective commitment. Personnel Psychology, 64(2), 315-350.

31. Goštautaitè, B., \&Bučiūnienè, I. (2015).Age, work engagement and individual work performance: the influence of work design. ISM University of Management and Economics.

32. Gruman, J. A., \& Saks, A. M. (2011).Performance management and employee engagement.Human Resource Management Review, 21(2), 123-136.

33. Hair, J. F., Ringle, C. M., \&Sarstedt, M. (2012). Partial least squares: the better approach to structural equation modeling? Long Range Planning, 45(5-6), 312-319.

34. Hair Jr, J. F., Sarstedt, M., Hopkins, L., \&Kuppelwieser, V. G. (2014). Partial least squares structural equation modeling (PLS-SEM).European Business Review, 26(2), 106-121.

35. Hameed, M. A., Ramzan, M., KashifZubair, H., Ali, G., \&Arslan, M. (2014).Impact of Compensation on Employee Performance (Empirical Evidence from Banking Sector of Pakistan).International Journal of Business and Social Science, 5(2),302-309.

36. Henseler, J., Ringle, C. M., \&Sinkovics, R. R. (2009). The use of partial least squares path modeling in international marketing. In Advances in International Marketing (Vol. 20, pp. 277-319).

37. Hosseini,S.M.,Sourati, P.,\&Kargar,M.(2015).ASurvey oftheRelationshipbetweenJobRotationand job Performance of the Managers of Bank Meli of Gilan Province.Journal of Applied Sciences Research, 11(1),60-65.

38. HumanRightWatch.(2016).Pakistan:OverhaulAbusivePoliceForce.RetrievedFebruary28,2020,from https://www.hrw.org/news/2016/09/26/pakistan-overhaul-abusive-police-force

39. Imran, M., Hamid, S. N. B. A., Aziz, A. B., \& Wan, C. Y. (2019). The effect of performance appraisal politics on employee performance in emergency services Of Punjab, Pakistan. Academy of Strategic Management Journal, 18(1), 1-7.

40. Inyang, B. J., \&Akaegbu, J. B. (2014).Redefining the Role of the Human Resource Professional (HRP) in the Nigerian Public Service for Enhanced Performance.International Journal of Business Administration, 5(1), 90-98. https://doi.org/10.5430/ijba.v5n1p90 
41. Iqbal, S., Farooq, M., \&Shabbir, M. (2019). Impact Assessment of the Climatic Variations on the Job Performance of Traffic Personnel in Punjab, Pakistan. Journal of the Research Society of Pakistan, 56(2), 375-385.

42. Ismail, A., Adnan, N., \& Bakar, R. (2014).Perceived career development support in workplace career programme.Economic Annals, 59(201), 157-175.

43. Issahaku, A., Ahmed, D., \&Bewa-Erinibe, P. L. (2014).Enhancing Employee Performance through Training: The Case of Tamale Teaching Hospital in Ghana.European Journal of Business and Management, 6(29), 147-158.

44. Jagero, N., Komba, H. V., \&Mlingi, M. N. (2012). Relationship between on the Job Training and Employees' Performance in Courier Companies in Dar es Salaam, Tanzania. International Journal of Humanities \& Social Science, 2(22), 114-120.

45. Jiang, K., Takeuchi, R., \&Lepak, D. P. (2013). Where do We Go From Here? New Perspectives on the Black Box in Strategic Human Resource Management Research. Journal of Management Studies, 5(8), 1448-1480.

46. Khalid, M. M., AbdulRehman, C., \& Ilyas, M. (2014). HRM Practices and Employee Performance in Public Sector Organizations in Pakistan: An Empirical study. International Journal of Management Sciences and Business Research, 3(2), 69-77.

47. Khan, F., Rasli, A. M., Yusoff, R. M., Ahmed, T., Rehman, A. ur, \& Khan, M. M. (2014). Job rotation, job performance, organizational commitment: An empirical study on bank employees. Journal of Management Info, 1(3), 10-13.

48. Khan,M.I.(2012).Theimpactoftrainingandmotivationonperformanceofemployees.BusinessReview, 7(2),84-95.

49. Khan, N. R., Raziq, A., \&Ghouri, A. M. (2019). Strategic Human Resource Management and Organizational Competitiveness in SMEs of Pakistan: Moderation Role of Regulatory Environment and Industry Characteristics. Journal of Business \& Economics, 11(2), 51-73.

50. Koopmans, L., Bernaards, C., Hildebrandt, V., van Buuren, S., van der Beek, A. J., \& de Vet, H. C. w. (2012). Development of an individual work performance questionnaire.International Journal of Productivity and Performance Management, 62(1), 6-28.

51. Krejcie, R. V., \& Morgan, D. W. (1970). Determining Sample Size for Research Activities.Educational and Psychological Measurement, 30(3), 607-610.

52. Laeeq, H., Shahzad, A., Ramalu, S., \&Habiba, U. (2016). AnIntervening Role of Organizational Support in The Relationship of Training \& Development And Technological Advancement with The PerformanceofPunjabPolicePakistan.JournalofQuality andTechnologyManagement,13(II),89- 113.

53. Marwat, Z. A., Qureshi, T. M., \&Ramay, M. I. (2006). Impact of human resource management (HRM) practices on employees performance: A Case of Pakistani Telecom Sector. International Journal.

54. Mohan, K., \&Gomathi, S. (2015). The Effects of Job Rotation Practices on Employee Development: An Empirical Study on Nurses in the Hospitals of Vellore District. Mediterranean Journal of Social Sciences, 6(1), 209-215.

55. Mone, E. M., \& London, M. (2018).Employee Engagement Through Effective Performance Management.

56. Nadarasa, T. (2013). The impact of perceived human resource practices on performance of the employees special reference to the telecommunication industry in jaffna district. Global General of Commerce \& Management Perspective, 2(6), 72-77.

57. Olubunmi, A. D., \&Adesopo, A. A. (2017).Public Financial Accountability Institutions and Democratic Governance in Nigeria.Canadian Social Science, 13(11), 1-12.

58. Oluigbo, I., \&Anyiam, K. (2014). The Role Of Compensation On Employee Performance In An InformationTechnologyOrganization.InternationalJournalofResearchinInformationTechnology (IJRIT), 2(4),548-558.

59. Oparanma, A., \&Nwaeke, L. (2015).Impact of Job Rotation on Organizational Performance.British Journal of Economics, Management \& Trade, 7(3), 183-187.

60. Osma, A. I. R. M. S. (2013). Effectiveness of communication style in performance appraisal systems.Journal of Yaşar University, 8(29), 4835-4852.

61. Paauwe, J. (2009). HRM and Performance: Achievements, Methodological Issues and Prospects. Journal of Management Studies, 46(1), 129-142.

62. Palvalin, M. (2019). What matters for knowledge work productivity? Employee Relations, 41(1), 209227.

63. Pavlou\&Fygenson.(2006).UnderstandingandPredictingElectronicCommerceAdoption:AnExtension of the Theory of Planned Behavior. MIS Quarterly, 30(1),115-143.

64. Pichler, S., Varma, A., Michel, J. S., Levy, P. E., Budhwar, P. S., \& Sharma, A. (2016). Leader-Member Exchange,Group-andIndividual-LevelProceduralJusticeandReactionstoPerformanceAppraisals.Human 
Resource Management, 55(5),871-883.

65. Pynes, J. E. (2009). Human resources management for public and nonprofit organizations: A strategic approach (3rd ed.). Jossey-Bass.

66. Quartey, S. H., \&Attiogbe, E. J. (2013). Is there a link between compensation packages and job performance in the Ghana police service? African Journal of Business Management, 77(4), 4398- 4406.

67. Ramos-Villagrasa, P. J., Barrada, J. R., Fernández-del-Río, E., \& Koopmans, L. (2019).Assessing Job Performance Using Brief Self-report Scales: The Case of the Individual Work Performance Questionnaire.Revista de Psicología Del Trabajo y de Las Organizaciones, 35(3), 195-205.

68. Rashki, Z., Hasanqasemi, A., \&Mazidi, A. (2014).The study of job rotation and staff performance in customsorganizationofGolestanandMazandaranProvinces.KuwaitChapterofArabianJournalof Business and Management Review, 3(7), 186-194.

69. Rehman, O., Mansoor, A., Rafiq, M., \& Rashid, M. (2011). Training and development, leadership style and empowerment practices as determinants of organization citizenship behavior in corporate sector of developing country Pakistan. Far East Journal of Psychology and Business, 4(2), 16-26.

70. Saravani, S. R., \&Abbasi, B. (2013).Investigating the influence of job rotation on performance by consideringskillvariationandjobsatisfactionofbankemployees.TehničkiVjesnik,20(3),473-478.

71. Sarstedt, M., Ringle, C. M., Henseler, J., \& Hair, J. F. (2014). On the emancipation of PLS-SEM: A commentary on Rigdon (2012). Long Range Planning, 47(3), 154-160.

72. Shahzad, Khuram, Bajwa, S. U., Ansted, R. B., Mamoon, D., \&Khaliq-ur-Rehman. (2016). Evaluating human resource management capacity for effective implementation of advanced metering infrastructure by electricity distribution companies in Pakistan. Utilities Policy, 41, 107-117.

73. Shahzad, Khurram, Bashir, S., \&Ramay, M. I. (2008). Impact of HR Practices on Perceived Performance of University Teachers in Pakistan.International Review of Business Research Papers, 4(2), 302-315.

74. Shehrani, S. (2017).Institutional Reform in Pakistan.

75. Singh, B. D. (2012). Compensation and Reward Management (2nd ed.). Excel Books, India.

76. Smith, A., \&Hayton, G. (1999). What drives enterprise training? Evidence from Australia.International Journal of Human Resource Management, 10(2), 251-272.

77. Sopiah, S. (2013). The effect of compensation toward job satisfaction and job performance of outsourcing employees of Syariah banks in Malang, Indonesia. International Journal of Learning Development, 3(2), 77-91.

78. Tabiu, A. (2019). Understanding the Effect of HRM Practices on Employees' Task Performance: An Empirical Evidence from Civil Service in Nigeria. Nile Journal of Business and Economics, 5(11), 3 15.

79. Tabiu, Abubakar, \&Nura, A. A. (2013). Assessing the effects of human resource management (HRM) practices on employee job performance: A study of UsmanuDanfodiyo University Sokoto. Journal of Business Studies Quarterly, 5(2), 247-259.

80. Tiwari, S. (2011).Employee engagement-the key to organizational success.In 10th International Conference on Operations and Quantitative Management (pp. 311-328).

81. Ullah, F., Hussain, S., \& Alam, H. (2016).Factors Influencing Police Image in Public (A Study of University Students Perception in KPK Pakistan).Pakistan Journal of Criminology, 8(3), 134.

82. Urbach,N.,andAhlemann,F.(2010).Structuralequationmodelingininformationsystemsresearchusing partial least squares.Journal of Information Technology Theory and Application (JITTA), 11(2), 5- 40.

83. Warf, B. (2019). Spatiality of Corruption in the Middle East and North Africa.In Global Corruption from a Geographic Perspective (pp. 83-109).Springer, Cham.

84. Way, S. A. (2002). High performance work systems and intermediate indicators of firm performance within the US small business sector. Journal of Management, 28(6), 765-785.

85. Wolf, S. O. (2017). Pakistan and State-Sponsored Terrorism in South Asia. In Terrorism Revisited (pp.109-155). Springer,Cham. 